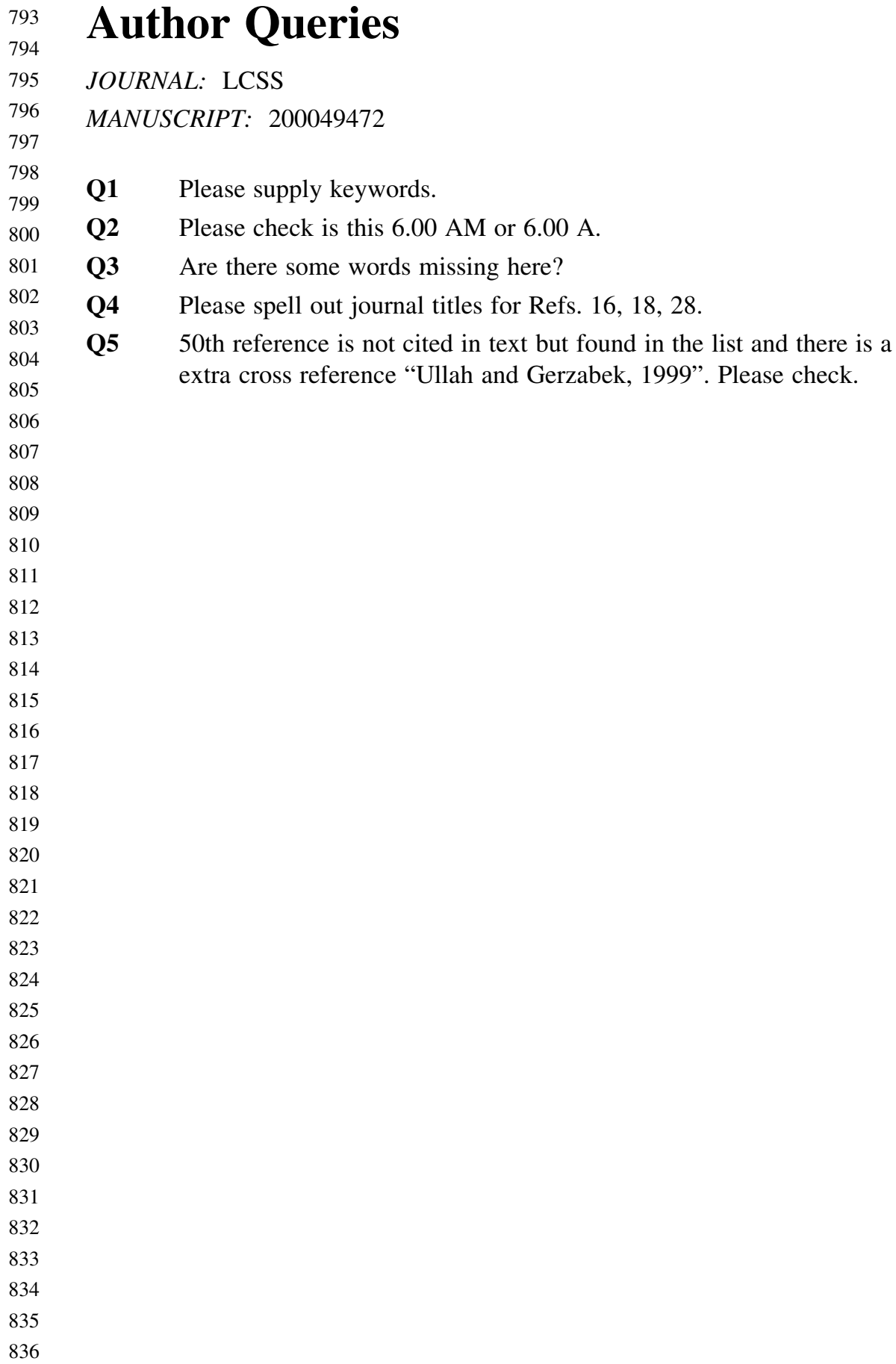


Communications in Soil Science and Plant Analysis, 36: 1-18, 2005

Copyright (C) Taylor \& Francis, Inc.

ISSN 0010-3624 print/1532-2416 online

DOI: $10.1081 / C S S-200049472$

\title{
Influence of Soil Amendments on Heavy Metal Accumulation in Crops on Polluted Soils of Bangladesh
}

\author{
A. S. Chamon \\ Department of Soil, Water and Environment, University of Dhaka, \\ Bangladesh \\ M. H. Gerzabek \\ Institute of Soil Research, University of Natural Resources and Applied \\ Life Sciences(BOKU), Vienna, Austria \\ M. N. Mondol \\ Aftab Biotech, ABFL, Bhagalpur, Bajitpur, Kishoregonj, Bangladesh \\ S. M. Ullah and M. Rahman \\ Department of Soil, Water and Environment, University of Dhaka, \\ Bangladesh \\ W. E. H. Blum \\ Institute of Soil Research, University of Natural Resources and Applied \\ Life Sciences (BOKU), Vienna, Austria
}

\begin{abstract}
Pot experiments with soils from three contaminated sites and an additional field experiment were conducted. The aim of the experiments was to test different organic and inorganic soil amendments to heavy metal uptake and to alleviate toxicity in different agricultural crops. Elements in the extracts were measured by
\end{abstract}

Received 12 April 2002, Accepted 16 September 2004

Address correspondence to M. H. Gerzabek, University of Natural Resources and Applied Life Sciences, Gregor-Mendel Strasse 33, A-1180, Vienna, Austria. Fax: 431476543130. E-mail: martin.gerzabek@boku.ac.at 
plasma emission spectroscopy (ICP-AES). Cadmium in the extracts was measured by atomic absorption spectroscopy (AAS), with a heated graphite-tube system (HGA). The results of the experiment were statistically evaluated by the LSD test. Almost all treatments had positive effects on crop productivity or reduced heavy metal uptake. Organic manures especially reduced manganese $(\mathrm{Mn})$, chromium $(\mathrm{Cr})$, and nickel $(\mathrm{Ni})$ uptake. Iron $(\mathrm{Fe})$ oxides contained in red mud, a by-product of the aluminum industry, reduced soil to plant transfer of zinc ( $\mathrm{Zn}), \mathrm{Ni}$, cadmium $(\mathrm{Cd})$, and $\mathrm{Cr}$. The results from these experiments show that it is necessary to select and combine amendments taking into account both site and crop characteristics.

Keywords: Please supply

\section{INTRODUCTION}

Bangladesh possesses many industrial sites, whereby waste water and solid wastes are directly discharged into the environment without any treatment or cleaning processes. Agricultural areas are contaminated thereby, and food quality is impaired.

Treatment of soils contaminated by trace metals is classically based on the application of lime and phosphates and the addition of organic matter (1). The addition of lime, however, does not always deliver the aimed effects on the solubility of trace metals (2). Heavy metals in soils are either retained by the solid phase or exist as ions in the soil solution, adsorbed on the soil colloids or as soluble organo-metallic complexes (3). The environmental effects and transport of heavy metals in a soil as well as their uptake by plants are governed by metal mobility (3). The adsorption and coprecipitation of toxic metals with colloidic hydrous oxides are important processes in decreasing metal availability (4). Lime, different types of organic matter, and iron oxides seem to be suitable soil amendments to stabilize soils polluted with heavy metals (5).

Because soil $\mathrm{pH}$ is a major factor governing micronutrient availability in soils, lime application might be expected to bring about changes in the levels of some extractable micronutrients. Available $\mathrm{Zn}, \mathrm{Mn}$, and Fe tend to be lower in soils with high $\mathrm{pH}$ values, whereas $\mathrm{Cu}$ is scarcely affected by soil $\mathrm{pH}(6-8)$. The $\mathrm{pH}$ of soil fundamentally modulates the behavior and availability of heavy metals in soil for plants, through adsorption or precipitation of metals, and formation of insoluble hydroxides, carbonates, and organic complexes (9-18). Adsorption of heavy metals onto clay minerals and organic matter is also increased with increasing soil $\mathrm{pH}$ conditions (9). The availability of trace elements to plants is generally larger at low $\mathrm{pH}$ than at high $\mathrm{pH}$, and the effect of an increase in soil $\mathrm{pH}$ value, by liming of soil, for example, is a reduction in metal absorption by plants (10).

The main objectives of the present research work were 1) to heavy metal uptake into crops through soil amendments with cow dung, city waste 
compost, water hyacinth, oil cake, and poultry litter and 2) to reduce heavy metal uptake into crops by applying lime and iron oxides.

\section{MATERIALS AND METHODS}

Pot experiments were conducted with contaminated soils from Tongi pharmaceutical, Tejgaon industrial, and Hazaribagh tannery areas, and also a field experiment was conducted at the Tejgaon industrial area. Soil samples were collected from the top layer $(0-15 \mathrm{~cm})$ for pot experiments. Different types of organic matter, lime, and iron oxides were added as remedial measures. The experiments were as follows.

\section{Experiment 1}

Organic manures applied on Tongi soil (pot exp.); rice variety, BR-11. Basal dose of fertilizer; urea $(46 \% \mathrm{~N})-0.39 \mathrm{~g}$, triple-superphosphate (TSP) $(45 \%$ $\left.\mathrm{P}_{2} \mathrm{O}_{5}\right)-0.10 \mathrm{~g}$, and $\mathrm{KCl}\left(60 \% \mathrm{~K}_{2} \mathrm{O}\right)-0.19 \mathrm{~g}$ per $8 \mathrm{~kg}$ soil/pot (BARC, 1997), with four replicates. Treatments: control, cow dung $(73 \mathrm{~g} / 8 \mathrm{~kg}$ soil), city waste compost $(73 \mathrm{~g} / 8 \mathrm{~kg}$ soil), oil cake (mustard, $73 \mathrm{~g} / 8 \mathrm{~kg}$ soil), water hycinth compost ( $73 \mathrm{~g} / 8 \mathrm{~kg}$ soil), poultry litter $(73 \mathrm{~g} / 8 \mathrm{~kg}$ soil).

\section{Experiment 2}

Lime applied on Tejgaon soil and Hazaribagh soil (pot exp.); test crops: rice, variety BR-28 (3 plants/pot), wheat, variety Kanchan (3 plants/pot) and tomato, variety Ratan (1 plant/pot). Basal dose of fertilizer at low rate for rice (11); urea $(46 \% \mathrm{~N})-0.56 \mathrm{~g}$, TSP $\left(45 \% \mathrm{P}_{2} \mathrm{O}_{5}\right)-0.13 \mathrm{~g}$, and $\mathrm{KCl}(60 \%$ $\left.\mathrm{K}_{2} \mathrm{O}\right)-0.27 \mathrm{~g}$ per $8 \mathrm{~kg}$ soil/pot, four replicates. Basal dose of fertilizer at low rate for wheat (11); urea $(46 \% \mathrm{~N})-0.50 \mathrm{~g}$, TSP $\left(45 \% \mathrm{P}_{2} \mathrm{O}_{5}\right)-0.15 \mathrm{~g}$, and $\mathrm{KCl}$ $\left(60 \% \mathrm{~K}_{2} \mathrm{O}\right)-0.26 \mathrm{~g}$ per $8 \mathrm{~kg}$ soil $/$ pot, four replicates. Basal dose of fertilizer at low rate for tomato (11); urea $(46 \% \mathrm{~N})-0.70 \mathrm{~g}$, TSP $\left(45 \% \mathrm{P}_{2} \mathrm{O}_{5}\right)-0.22 \mathrm{~g}$, and $\mathrm{KCl}\left(60 \% \mathrm{~K}_{2} \mathrm{O}\right)-0.51 \mathrm{~g}$ per $8 \mathrm{~kg}$ soil/pot, four replicates. Treatment: $36 \mathrm{~g} / 8 \mathrm{~kg}$ soil limestone (calcitic) (powder form).

\section{Experiment 3}

A microplot field experiment, size of plots; $(1 \mathrm{~m} \times 1 \mathrm{~m})^{2}$, with rice, variety BR-28 was conducted on Tejgaon industrial area. Lime (calcitic) (powder form) $(10 \mathrm{t} / \mathrm{ha})$ was applied as a treatment. Rice was harvested at flowering stage with four replicates. 


\section{A. S. Chamon et al.}

\section{Experiment 4}

Pot experiment with red mud application. Soils: Hazaribagh tannery soil, Tejgaon soil, $8 \mathrm{~kg} /$ pot, crop: rice, variety BR-28, 3 plants/pot, four replicates. Treatment: $80 \mathrm{mg}$ red mud/pot.

Soil samples were digested with $\mathrm{HCl}: \mathrm{HNO}_{3}(3: 1)$, and plant samples were digested with a $\mathrm{HNO}_{3}: \mathrm{HClO}_{4}(5: 1)$ mixture in closed systems. All elements with exception of $\mathrm{Cd}$ and $\mathrm{Hg}$ were measured in the extracts by plasma emission spectroscopy (ICP-AES) (12). Cadmium was measured in the extracts by atomic absorption spectroscopy (AAS), with a heated graphitetube system (HGA) (12). Mercury (in soil) was measured by AAS and mercury-hydride system (MHS-20) (12). A gold-platinum net was used in Hg determination.

The results of the experiment were statistically evaluated by the LSD test (12). The latter was used for testing the significance of differences between mean values. The 0.05 level of probability was chosen for the statistical judgment.

\section{RESULTS}

\section{Organic Manures}

Carbon and nitrogen $(\mathrm{N})$ contents of the five applied organic materials varied considerably. The highest nitrogen content was in oil cake (5.24\%), followed by cow dung $(1.99 \%)$, poultry litter $(1.44 \%)$, water hyacinth $(0.49 \%)$, and city waste $(0.47 \%)$. The $\mathrm{pH}$ values of all organic materials were between 6.34 and 7 , neutral or slightly acid. Excluding the city waste compost, which exhibits allevated levels of $\mathrm{Zn}(508 \mathrm{mg} / \mathrm{kg})$, lead $(\mathrm{Pb})(173 \mathrm{mg} / \mathrm{kg}), \mathrm{Cd}(2.8 \mathrm{mg} / \mathrm{kg})$, copper $(\mathrm{Cu})(297 \mathrm{mg} / \mathrm{kg})$, and mercury $(\mathrm{Hg})(514 \mathrm{mg} / 1000 \mathrm{~kg})$, all organic materials can be classified as less contaminated and suitable for agricultural use according to their heavy metal concentrations. Manganese contents were higher in cow dung, water hyacinth, and poultry litter. C:N ratios of the organic material ranged from 7.2 (oil cake) to 15.8 (poultry litter). Oil cake had an extremely low value.

\section{Tongi Soils}

The amendment of organic residues did not significantly alter rice grain yields (Table 1). Oil cake showed a negative influence on plant growth and city waste compost seemed to improve yields followed by poultry litter and water hyacinth compost (Table 1). Accumulation of manganese (Mn), chromium 
Soil Amendments and Heavy Metal Accumulation

Table 1. Impact of organic manures on heavy metal concentration, rice variety BR-11

\begin{tabular}{|c|c|c|c|c|c|c|}
\hline \multirow[b]{2}{*}{ Parameter } & \multicolumn{6}{|c|}{ Rice grain } \\
\hline & $\begin{array}{l}\text { Control (no } \\
\text { amendment) }\end{array}$ & $\begin{array}{l}\text { Cow } \\
\text { dung }\end{array}$ & $\begin{array}{c}\text { City } \\
\text { waste }\end{array}$ & Oil cake & $\begin{array}{c}\text { Water } \\
\text { hyacinth }\end{array}$ & $\begin{array}{c}\text { Poultry } \\
\text { litter }\end{array}$ \\
\hline & \multicolumn{6}{|c|}{ Rice grain (mb/kg) } \\
\hline DM & $92.5 \mathrm{~B}$ & $105 B$ & 106.3B & $57.7 \mathrm{~A}$ & $96.3 \mathrm{~B}$ & $96.8 \mathrm{~B}$ \\
\hline Mn & $52 \mathrm{~A}$ & $44 \mathrm{~A}$ & $55 \mathrm{~A}$ & $48 \mathrm{~A}$ & $36 \mathrm{~A}$ & $41 \mathrm{~A}$ \\
\hline $\mathrm{Zn}$ & $20.3 \mathrm{~A}$ & $26 \mathrm{AB}$ & $25 \mathrm{AB}$ & $31 \mathrm{~B}$ & $24 \mathrm{AB}$ & $21 \mathrm{~A}$ \\
\hline $\mathrm{Cu}$ & $6.3 \mathrm{~A}$ & $6.3 \mathrm{~A}$ & $6.3 \mathrm{~A}$ & $6.8 \mathrm{~A}$ & $6.5 \mathrm{~A}$ & $6.8 \mathrm{~A}$ \\
\hline $\mathrm{Ni}$ & $2.46 \mathrm{~B}$ & $2.27 \mathrm{~B}$ & $1.53 \mathrm{~A}$ & $1.37 \mathrm{~A}$ & $1.56 \mathrm{~A}$ & $1.19 \mathrm{~A}$ \\
\hline $\mathrm{Cd}$ & $0.05 \mathrm{~A}$ & $0.04 \mathrm{~A}$ & $0.02 \mathrm{~A}$ & $0.03 \mathrm{~A}$ & $0.05 \mathrm{~A}$ & $0.04 \mathrm{~A}$ \\
\hline \multirow[t]{2}{*}{$\mathrm{Cr}$} & $4.06 \mathrm{C}$ & $3.63 \mathrm{C}$ & $2.61 \mathrm{~B}$ & $1.86 \mathrm{AB}$ & $2.29 \mathrm{AB}$ & $1.42 \mathrm{~A}$ \\
\hline & \multicolumn{6}{|c|}{ Rice shoot (mg/kg) } \\
\hline DM & $156.3 \mathrm{~A}$ & $155 \mathrm{~A}$ & $172.5 \mathrm{~A}$ & $137.5 \mathrm{~A}$ & $168.8 \mathrm{~A}$ & $131.3 \mathrm{~A}$ \\
\hline $\mathrm{Mn}$ & $362 \mathrm{~A}$ & $356 \mathrm{~A}$ & $365 \mathrm{~A}$ & $318 \mathrm{~A}$ & 159B & 129B \\
\hline $\mathrm{Zn}$ & $76 \mathrm{~A}$ & $134 \mathrm{~B}$ & $96 \mathrm{~A}$ & $96 \mathrm{~A}$ & $106 \mathrm{AB}$ & $104 \mathrm{~A}$ \\
\hline $\mathrm{Cu}$ & 8.7AB & 8.9AB & $9.8 \mathrm{ABC}$ & $10.9 \mathrm{C}$ & $7.9 \mathrm{~A}$ & $10.5 \mathrm{BC}$ \\
\hline $\mathrm{Ni}$ & $0.91 \mathrm{~B}$ & $0.61 \mathrm{~A}$ & $0.91 \mathrm{~B}$ & $0.62 \mathrm{AB}$ & $0.67 \mathrm{AB}$ & $0.51 \mathrm{~A}$ \\
\hline $\mathrm{Cd}$ & $0.06 \mathrm{AB}$ & $0.07 \mathrm{AB}$ & $0.07 \mathrm{AB}$ & $0.05 \mathrm{~A}$ & $0.1 \mathrm{~B}$ & $0.07 \mathrm{AB}$ \\
\hline $\mathrm{Cr}$ & $0.99 \mathrm{AB}$ & $0.72 \mathrm{AB}$ & $0.91 \mathrm{AB}$ & $0.74 \mathrm{AB}$ & 1.33B & $0.57 \mathrm{~A}$ \\
\hline
\end{tabular}

Mean values with the same letters in rows are not significantly different $(p \leq 0.05)$ by LSD test. DM, dry matter.

$(\mathrm{Cr})$, and nickel $(\mathrm{Ni})$ in rice straw and grains were suppressed by organic residue applications (Table 1).

\section{Pot Experiments on Tejgaon Soil}

Rice

Dry weights (DW) of grain, shoot, and root were significantly lower in the unpolluted soil from Bajitpur than on the Tejgaon soil. Higher soil fertility of the Tejgaon soil, compared with the Bajitpur soil (probably due to a more favorable $\mathrm{pH}$ and a considerably higher $\mathrm{N}_{\mathrm{t}}$ ), produced high yields (Table 2).

Liming of the Tejgaon soil did not result in significant changes in yield parameters of variety BR-28, which implies that soil fertility was not improved by liming or heavy metals at levels present seem not to have a negative influence on rice productivity on this soil. Moreover, there was a tendency for improved root growth in the lime treated pots (14). Root fresh 


\section{A. S. Chamon et al.}




Soil Amendments and Heavy Metal Accumulation

265

266

267

268

269

270

271

272

273

274

275

276

277

278

279

280

281

282

283

284

285

286

287

288

289

290

291

292

293

294

295

296

297

298

299

300

301

302

303

304

305

306

307

308

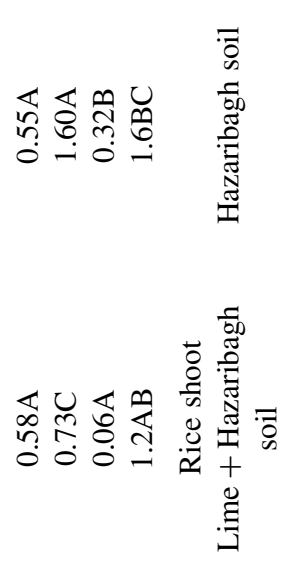

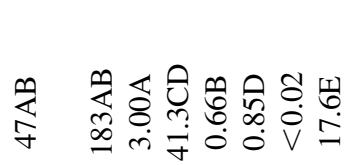



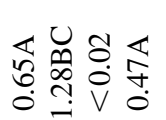

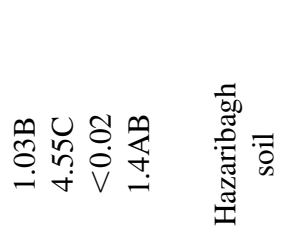

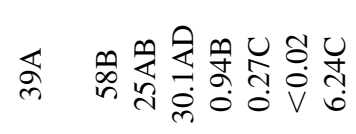

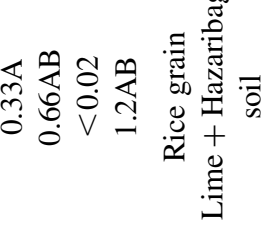

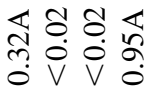

○े V ! : :

๓

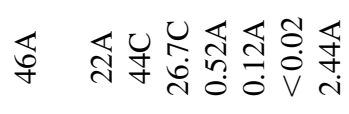

Oि 000000

कo 00 on

$\Xi \Xi \Xi \Xi$

艺官

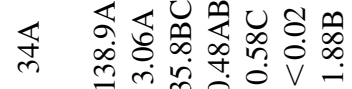
$\stackrel{00}{\Xi 00}$ 
and dry weight and root length seemed to be positively influenced by the lime treatment (Table 3).

Micronutrient concentrations, especially manganese $(\mathrm{Mn})$, copper $(\mathrm{Cu})$, zinc $(\mathrm{Zn})$, and chromium $(\mathrm{Cr})$ were 2.0, 1.68, 2.32, and 3.49 times higher in shoots of BR-28 on Tejgaon soil compared with the shoots of BR-28 on Bajitpur soil (Table 2). Also in grains a similar trend was observed. Manganese, $\mathrm{Cu}, \mathrm{Ni}$, and $\mathrm{Cr}$ accumulation in grains of BR-28 were 1.39, 1.13, 3.22, and 1.46 times higher, respectively, on Tejgaon soil than on Bajitpur soil (Table 2). The grains of BR-28 on Tejgaon soil accumulated significantly higher amounts of $\mathrm{Pb}$ compared to the Bajitpur soil.

The ameliorative effect of lime was clearly observed for the Tejgaon soil. Manganese, zinc ( $\mathrm{Zn})$, lead $(\mathrm{Pb})$, and $\mathrm{Cr}$ concentrations were 54\%, 40\%, 54\%, and $55 \%$ lower in shoots of BR-28, and $\mathrm{Mn}, \mathrm{Zn}$, nickel $(\mathrm{Ni}), \mathrm{Pb}$, and $\mathrm{Cr}$ concentrations were $23 \%, 3.8 \%, 68 \%, 85.9 \%$, and $14 \%$ lower in grains of BR-28 in limed pots compared to the unlimed pots (Table 2).

Wheat

The variety Kanchan exhibited the highest grain yield, followed by Akbar and Agrani. Kanchan did not show significantly different grain yields and shoot length on Tejgaon and Bajitpur soil. However, straw biomass and the number of tillers were significantly lower on Bajitpur soil, which reflects once again the poor nitrogen status of this soil. The lower number of tillers was compensated by a significantly higher 1000-grain weight on the Bajitpur soil. No significant difference in 1000-grain weight occurred among the varieties.

As observed for rice, lime treatments had no significant influence on wheat yield parameters. Nitrogen, sulfur $(\mathrm{S})$, magnesium $(\mathrm{Mg})$, calcium (Ca), copper $(\mathrm{Cu})$, zinc $(\mathrm{Zn})$, nickel $(\mathrm{Ni})$, and chromium $(\mathrm{Cr})$ concentration in grains were $32 \%, 11.6 \%, 29.1 \%, 356 \%, 71 \%, 832 \%, 11.6 \%$, and $119 \%$ higher on Tejgaon soil than on the Bajitpur soil, which was considered as unpolluted agricultural soil. Lead concentration in wheat grain (varietyKanchan) were also significantly higher on Tejgaon soil $(6.24 \mathrm{mg} / \mathrm{kg})$ than on the unpolluted Bajitpur soil (Figure 1).

\section{Tomato}

The response of tomato was clearly different from the two cereal species described above (Table 2). Most of the yield parameters were lowest for the Bajitpur soil; especially tomato fruit fresh matter and shoot dry matter production on Bajitpur soil were significantly lower than on the Tejgaon soil. Bajitpur soil exhibited 53\% lower shoot DW than the Tejgaon soil, which reflects once again the poor nitrogen status of the Bajitpur soil. Also DW of tomato fruit production was significantly higher by $48 \%$ in limed pots 
Soil Amendments and Heavy Metal Accumulation

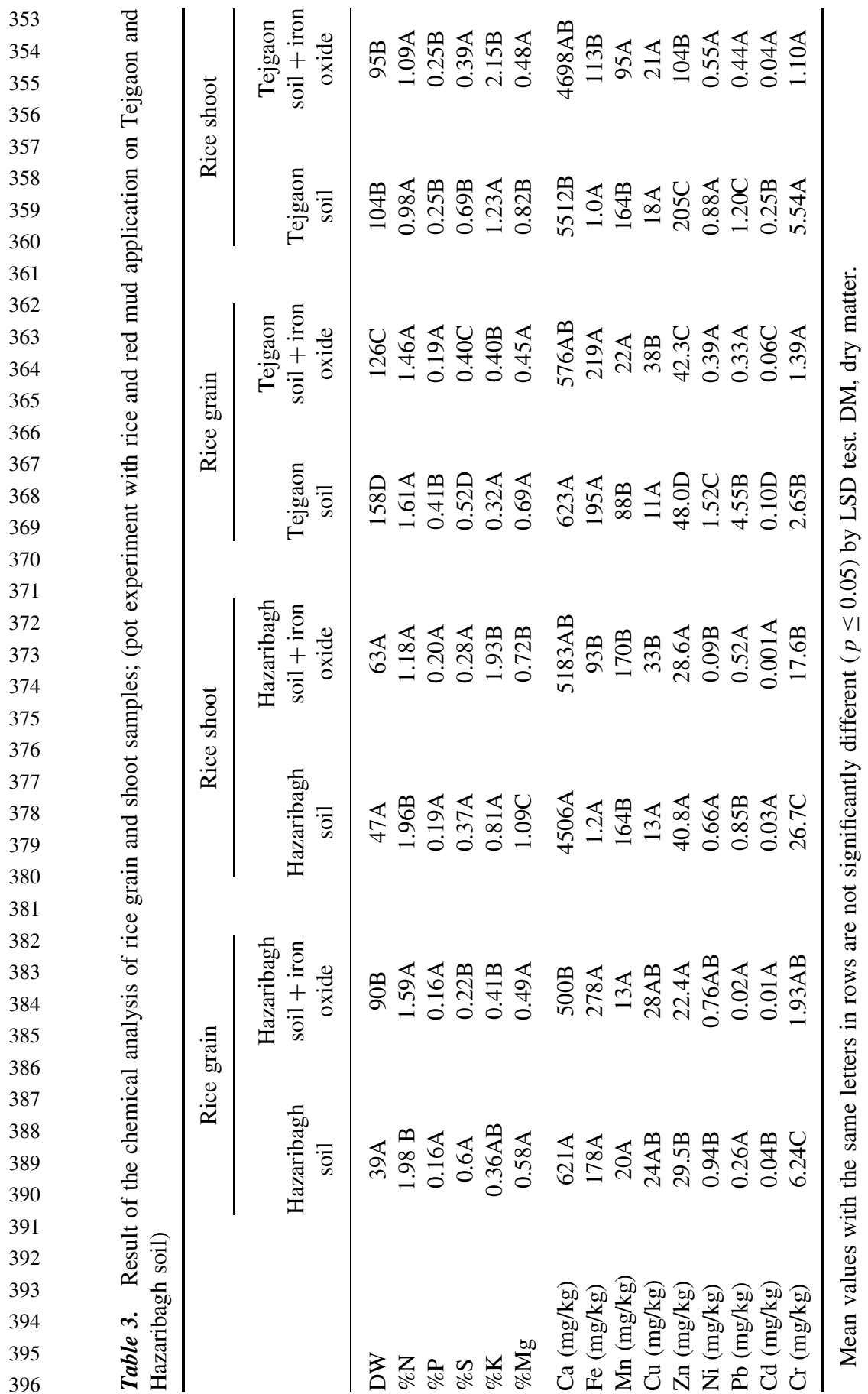




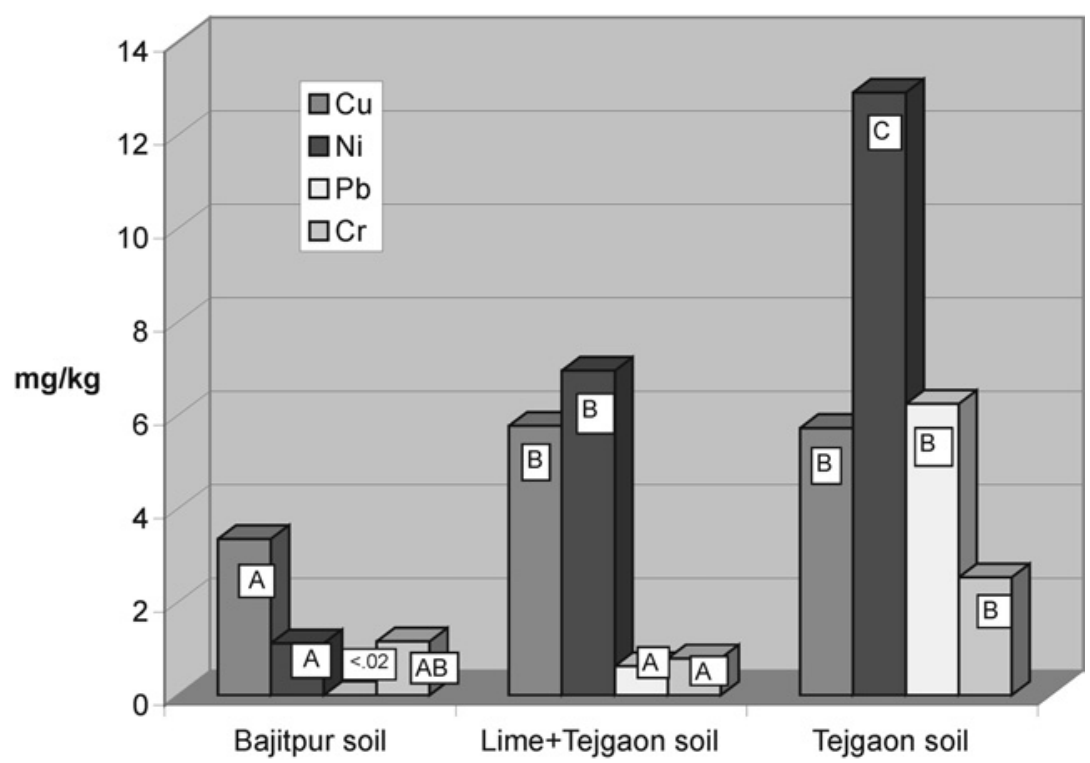

Figure 1. Effect of liming on $\mathrm{Cu}, \mathrm{Ni}, \mathrm{Pb}$, and $\mathrm{Cr}$ concentrations of wheat grains on Tejgaon soil. Histograms with same letters are not significantly different $(p \leq 0.05)$ by LSD test.

compared to the unlimed pots with Tejgaon soil. This effect of liming could be due to heavy metal toxicity in the Tejgaon soil, which was alleviated by the lime treatment and this is supported by the results of the heavy metal analyses (Table 2). Considering the limit values for heavy metals in plants, tomato shoots on Tejgaon soil concentrated more manganese $(\mathrm{Mn})$, copper $(\mathrm{Cu})$, zinc $(\mathrm{Zn})$, nickel $(\mathrm{Ni})$, lead $(\mathrm{Pb})$, and chromium $(\mathrm{Cr})$ than the permissible value (19). The tomato fruits on Tejgaon soil accumulated 4 times more $\mathrm{Cr}$ than the limit value. Due to lime application in Tejgaon soil, a tendency of increasing $\mathrm{Cu}$ concentration was observed for both shoots and fruits (Table 2).

\section{Microplot Field Experiment with Rice on Tejgaon Soils}

Liming did not significantly affect yield parameters but significantly ameliorated heavy metal concentration in rice (BR-28) shoots and roots. Manganese, $\mathrm{Zn}, \mathrm{Ni}, \mathrm{Pb}, \mathrm{Cd}$, and $\mathrm{Cr}$ concentrations were less in shoots on limed plots than on unlimed plots (Table 4). Liming increased $\mathrm{Cu}$ accumulation into rice shoots of variety BR-28 considerably (Figure 2). Copper concentration was also 
Table 4. Results of chemical analysis of rice samples (variety, BR-28); microplot field experiment on Tejgaon soil, test of lime treatment ( 25 seedlings/plot)

\begin{tabular}{lccccc}
\hline & \multicolumn{2}{c}{ Shoot } & & \multicolumn{2}{c}{ Root } \\
\cline { 2 - 3 } \cline { 5 - 6 } Parameter & $\begin{array}{c}\text { Lime + Tejgaon } \\
\text { soil }\end{array}$ & $\begin{array}{c}\text { Tejgaon } \\
\text { soil }\end{array}$ & & $\begin{array}{c}\text { Lime + Tejgaon } \\
\text { soil }\end{array}$ & $\begin{array}{c}\text { Tejgaon } \\
\text { soil }\end{array}$ \\
\hline $\mathrm{DW}, \mathrm{kg} / \mathrm{plot}$ & $2.92 \mathrm{~A}$ & $3.22 \mathrm{~A}$ & & $0.39 \mathrm{~A}$ & $0.54 \mathrm{~A}$ \\
$\mathrm{Length}, \mathrm{cm}$ & $83 \mathrm{~B}$ & $86 \mathrm{~B}$ & & $52 \mathrm{~A}$ & $49 \mathrm{~A}$ \\
$\mathrm{Mn}(\mathrm{mg} / \mathrm{kg})$ & $91 \mathrm{~A}$ & $157 \mathrm{~B}$ & & $42 \mathrm{~A}$ & $55 \mathrm{~A}$ \\
$\mathrm{Cu}(\mathrm{mg} / \mathrm{kg})$ & $161 \mathrm{~B}$ & $24 \mathrm{~A}$ & & $44 \mathrm{~A}$ & $36 \mathrm{~A}$ \\
$\mathrm{Zn}(\mathrm{mg} / \mathrm{kg})$ & $46 \mathrm{~A}$ & $91 \mathrm{~B}$ & & $174 \mathrm{~A}$ & $197 \mathrm{~A}$ \\
$\mathrm{Ni}(\mathrm{mg} / \mathrm{kg})$ & $2.3 \mathrm{~A}$ & $4.0 \mathrm{~B}$ & & $12 \mathrm{~A}$ & $19 \mathrm{~B}$ \\
$\mathrm{~Pb}(\mathrm{mg} / \mathrm{kg})$ & $2.3 \mathrm{~A}$ & $9.7 \mathrm{~B}$ & & $16 \mathrm{~A}$ & $36 \mathrm{~B}$ \\
$\mathrm{Cd}(\mathrm{mg} / \mathrm{kg})$ & $0.02 \mathrm{~A}$ & $0.05 \mathrm{~B}$ & & $0.10 \mathrm{~A}$ & $0.05 \mathrm{~A}$ \\
$\mathrm{Cr}(\mathrm{mg} / \mathrm{kg})$ & $2.2 \mathrm{~A}$ & $4.9 \mathrm{~B}$ & & $20 \mathrm{~A}$ & $37 \mathrm{~B}$ \\
\hline
\end{tabular}

increased by $22 \%$ in rice roots due to liming. A similar effect of lime was observed in the pot experiments with wheat and tomato plants.

\section{Pot Experiment with Rice on Hazaribagh Soil}

Biomass production by BR-28 on Hazaribagh soil was significantly different from that on Bajitpur soil. BR-28 produced significantly higher shoot length on Bajitpur soil than on Hazaribagh soil. Liming increased grain yields (DW) by $15 \%$ on Hazaribagh soil compared with the unlimed pots



Figure 2. Effect of liming on $\mathrm{Mn}, \mathrm{Cu}$, and $\mathrm{Zn}$ concentrations of rice shoots on Tejgaon soil (micro-plot field experiment). Histograms with same letters are not significantly different $(P \leq 0.05)$ by LSD test. 
(Table 2). Because of the ameliorative effect of lime, $\mathrm{Zn}, \mathrm{Ni}, \mathrm{Pb}$, and $\mathrm{Cr}$, concentrations of shoots and grains of BR-28 were reduced significantly as compared to the unlimed pots.

\section{Pot Experiments on Hazaribagh and Tejgaon Soil with Rice and Red Mud Application}

Another pot experiment with the Hazaribagh soil and the Tejgaon soil and rice focused on the effect of red mud application on heavy metal toxicity and accumulation.

In the Hazaribagh soil, red mud ameliorated plant growth and yield parameters significantly (Table 3 ). Grain yield increased by more than a factor of 2 . The 1000-grain weight, shoot length, and biomass production were positively influenced as well. On Tejgaon soil, the effect of red mud on grain yield production was less clear. Grain yields decreased significantly with red mud application, but 1000-grain weight and shoot length increased by $8 \%$ and $6 \%$, respectively. The suppression of grain yield might be due to a lower availability of macronutrients in red mud treated pots (Table 3 ).

The chemical analysis of rice shoot and grain samples clearly reflected the heavy metal toxicity symptoms of the rice plants (Table 3) (e.g., heavy metal chlorosis was clearly demonstrated by the low Fe contents in rice shoots on not-amended soils). On Hazaribagh soil, plants in red mud-treated pots exhibited significantly lower $\mathrm{N}, \mathrm{Mg}$, and slightly lower $\mathrm{S}$ accumulation in shoots, and in grains significantly lower N, S, and Ca accumulation than in the pots without red mud. On the other hand, potassium $(\mathrm{K})$ and Ca concentrations increased in shoots and also $\mathrm{K}$ in grains. On Tejgaon soil, $\mathrm{N}$ and $\mathrm{K}$ accumulation in shoots and $\mathrm{K}$ in grains of BR-28 increased on red mudtreated pots, but accumulation of other macro-nutrients decreased in shoots and grains.

Heavy metal accumulation by BR-28 was significantly ameliorated in both soils. Manganese accumulation by rice shoots on Hazaribagh soil was not significantly different although its concentration was above the toxic limit (40-100 mg Mn/kg). On Tejgaon soil, red mud diminished Mn concentration into rice shoots by $42 \%$. On Hazaribagh and Tejgaon soil, $35 \%$ and $75 \%$ less $\mathrm{Mn}$ was concentrated in the grains of BR-28, respectively, following red mud application. Red mud application suppressed $\mathrm{Cu}, \mathrm{Zn}, \mathrm{Ni}$, $\mathrm{Pb}, \mathrm{Cd}$, and $\mathrm{Cr}$ concentration in shoots of BR-28 by $61 \%, 30 \%, 86 \%, 39 \%$, $97 \%$ and $34 \%$, respectively, compared to the untreated pots with Hazaribagh soil (Table 3). On Tejgaon soil, $\mathrm{Cu}, \mathrm{Ni}$, and $\mathrm{Cr}$ accumulations by shoots were not significantly different among treatments, but $49 \%, 63 \%$, and $84 \%$ less $\mathrm{Zn}$, $\mathrm{Pb}$ and $\mathrm{Cd}$ concentrations were observed, respectively, due to red mud application. The ameliorative effect of red mud application was also clearly observed in the grain samples for both soils. Zinc, $\mathrm{Ni}, \mathrm{Pb}, \mathrm{Cd}$, and $\mathrm{Cr}$ 
concentration into rice grains diminished by $24 \%, 19 \%, 92 \%, 75 \%$, and $69 \%$, respectively, due to red mud application on Hazaribagh soil (Table 3). On Tejgaon soil, the grains of BR-28 exhibited 71\%, 12\%, 74\%, 93\%, 40\%, and $48 \%$ lower $\mathrm{Cu}, \mathrm{Zn}, \mathrm{Ni}, \mathrm{Pb}, \mathrm{Cd}$, and $\mathrm{Cr}$ accumulation on red mudtreated pots compared with the untreated pots (Table 3 ).

\section{DISCUSSION}

The dry matter yield of rice grain was increased $27 \%$ by the application of cowdung, which was also reported before (19). The short root lengths in the city waste-treated pots probably exerted toxicity due to heavy metals contained in it. Reduction in shoot and root length was due to heavy metal toxicity (Ullah and Gerzabek, 1990) (17, 20-22). The positive influence of organic substances on plant growth is a well-known phenomenon, which is due to indirect effects of humic substances acting as suppliers and regulators of plant nutrients and due to direct effects of humic substances (e.g., as respiratory catalysts) $(23,24)$. On the other hand, oil cake exerted some toxic effect on physiological functions, especially in the process of grain production. This may be in connection with the unfavorable $\mathrm{C}: \mathrm{N}$ ratio of the oil cake of approximately 7 , which resulted in the highest nitrogen concentration in biomass in this treatment. The uncontrolled use of organic materials may give rise to problems due to their high salinity or high heavy metal contents (25). They can block the present nitrogen by inducing a competition between microorganisms and plants, diminishing the oxygen at the root level or raising the temperature in such a way so that levels are reached plant are incompatible with normal plant development. They can also cause an accumulation of phytotoxic substances such as organic acids of low molecular weight and different pathogenic organisms $(26,27)$. The adsorption of metal could be ascribed more to the type than to the amount of organic matter (28-31). The complexation of heavy metals with organic matter affects the distribution of metal ions between the adsorbed and soluble phases of the soil (32), and the positive effect of organic compost on adsorption and retention of $\mathrm{Zn}$ and $\mathrm{Cd}$ in soil is well known $(33,34)$. Grains and roots of rice (BR-11) had the highest concentration of $\mathrm{Zn}$ in oil cake amendments $(31 \mathrm{mg} / \mathrm{kg}$ ). The significantly larger increase in $\mathrm{Zn}$ content due to oil cake addition can be explained by possible changes in metal complexation that took place during composting which may have increased the availability of $\mathrm{Zn}$ for rice (35). Muck and manure were the two best soil amendments, which showed a $73 \%$ and $63 \%$ reduction of $\mathrm{Pb}$ uptake, respectively, in soils with a $25 \%$ (by volume) addition of organic matter (16). The importance of increased cation exchange capacity and organic matter in reducing $\mathrm{Pb}$ uptake was already emphasized $(28,36-38)$. 
Fresh weight of tomato shoot and dry weight of tomato fruits were significantly enhanced in limed pots compared with the unlimed pots with Tejgaon soil. The positive effect of liming on tomato yields was also reported especially for acid soils (39).

The ameliorative effect of lime was clearly observed in Tejgaon and Hazaribagh soil for the three crops and for both pot and field experiments. When soil $\mathrm{pH}$ increased, root absorption of most heavy metal cations decreases. Available $\mathrm{Zn}$ and $\mathrm{Mn}$ tend to be lower in soils with higher $\mathrm{pH}$ values, reported by many workers $(8,40)$. The $\mathrm{Cr}$ concentration in shoots and grains were extremely low in comparison with total concentration on Hazaribagh soil. Tannery waste application increased total $\mathrm{Cr}$ levels of soil but did not result in significantly increased $\mathrm{Cr}$ concentration in wheat grain (40). The general toxicity limit for $\mathrm{Cr}$ is $1-2 \mathrm{ppm}$ (41). It is most interesting that liming increased $\mathrm{Cu}$ uptake into rice shoots of variety BR-28 considerably. At the first glance, this result seems to be an artefact. One would expect a decrease in $\mathrm{Cu}$ uptake by liming an acid soil like the Tejgaon soil. However, there is sufficient evidence in the literature $(42,43)$ that liming increase $\mathrm{Cu}$ availability to plants by enhancing mineralization of soil organic matter and at the same time inducing a higher portion of copper being present in soil solution in the form of organic chelates. In our case, $\mathrm{Cu}$ concentrations in rice shoot tissues even reached values suggested to be toxic according to the literature, after liming, although yield parameters did not show toxicity clearly. It is also interesting that liming diminished both $\mathrm{Mn}$ and $\mathrm{Zn}$ concentrations by a factor of 2 in BR-28.

Iron and $\mathrm{Mn}$ oxides are known to absorb or complex metallic ions. Several studies have been undertaken to determine the influence of these oxides on the extractable concentrations of metals in soils (44). Reduced conditions can be achieved by adding ferrous iron. For example, under reduced conditions mobile $\mathrm{Cr}$ (VI) will be converted to $\mathrm{Cr}$ (III), which precipitates readily in normal soil $\mathrm{pH}$ ranges (45). The addition of ferrous sulfate to soils contaminated with chromate washing residue in Japan was successful in reducing soluble hexavalent $\mathrm{Cr}$ to insoluble trivalent chromium (46). Hydrous oxides of $\mathrm{Fe}$ are well known to enhance metal immobilization in soils $(47,48)$. Thirty-five to $50 \%$ decrease in $\mathrm{Ni}$ uptake by the shoot of ryegrass in hydrous iron oxide treated pots compared with the untreated pots was reported by many authors (47-49), which supports our findings.

\section{CONCLUSION}

The amendment by organic residues significantly improved soil fertility indicated by an increase of harvested rice. Cow dung was shown to be most effective, followed by city waste compost, poultry litter, and water hyacinth compost. Oil cake showed a negative influence on plant growth. Contents of 
$\mathrm{Mn}, \mathrm{Cr}$, and $\mathrm{Ni}$ in rice straw and in rice grains were reduced by organic residue applications. The tested cereal crops after lime application on Tejgaon soil did not show a significant effect in harvested yield. For tomato plants, however, after liming the biomass yield was nearly doubled. Also at the Hazaribagh site, the positive effect of liming was proven. In all experiments, liming led to a significant suppression of heavy metal transfer into above ground biomass and into harvested products. Only $\mathrm{Cu}$ showed an aberrant behavior: for this element no reduction was observed. Applied in small amounts, the ferric oxides led to an increase in biomass production and improved yield for rice plants and caused significant reductions of soil to plant transfer of $\mathrm{Zn}, \mathrm{Ni}, \mathrm{Cd}$, and $\mathrm{Cr}$. In summary, it may be stated that all investigated methods (selection of suitable plant varieties as described in part 1 of the publication, lime application, soil amendments with organic residues and red mud) caused partly significant reductions of heavy metal accumulation from contaminated soils. Nevertheless, for the optimization of the reduction effects, it is necessary to select and combine the different methods according to site specific and variety specific characteristics.

\section{REFERENCES}

1. Kabata-Pendias, A. and Pendias, H. (1992) Trace Metals in Soils and Plants; 1-10, Boca Raton, FL: CRC Press.

2. Benninger, T.M. and Taylor, D.H. (1993) Municipal sludge metal contamination of old-field ecosystems: do liming and tilling affect remediation? Environmental Toxicology and Chemistry, 12: 1931-1943.

3. Cottenie, A. (1980) Behaviour and biological importance of heavy metals in the soil. Chemia, 34: 344-350.

4. Amacher, M.C., Kotuby-Amacher, J., Slim, H.M., and Iskandar, I.K. (1988) Retention and release of metals by soils-evaluation of several models. Geoderma, 38: 131-154.

5. Cunningham, S.D. and Berti, W.R. (1993) Remediation of contaminated soils with green plants: an overview. In Vitro Cellular and Development Biology, 29: 207-212.

6. Reith, J.W.S. (1983) Trace elements in soil and garbage. Norgrass, 23: 15-27.

7. Davies, D.B., Eagle, D.J., and Finney, J.B. (1979) Soil Management; 47-53, Suffolk, UK: Farming Press Ltd.

8. M.A.F.F. (Ministry of Agriculture, Forestry and Fisheries). (1981) Lime and Liming: Reference Book, 35. London: H.M.S.O.

9. Kiekens, L. (1984) Behaviour of heavy metals in soils. In Utilization of SewageSludge on Land: Rates of Application and Long Term Effects of Metals; Berglund, S., L'Hermite, P. and Davis, R.D., eds.; 126-134, Dordrecht, Netherlands: D. Riedel Publishing Company.

10. Davis, R.D. and Coker, E.G. (1980) Cadmium in Agriculture, with Special Reference to the Utilization of Sewage Sludge on Land; Tech. Report, 139, TR, Wrc Medmenham: Marlow, NH. 
11. BARC (Bangladesh Agricultural Research Council). (1997). Fertilizer Recommendation Guide, Vol. 41, 25-48. Dhaka, Bangladesh: Krishi Khamar Sarak.

12. Blum, W.E.H., Spiegel, H., and Wenzel, W.W. (1996) BodenzustandsinventurKonzeption, Durchführung und Bewertung. Bundesministerium für Land- und Forstwirtschaft 2nd ed.; Inst. für Bodenforschung, 102, Vienna: Univ. Für Bodenkultur.

13. Adriano, D.C. (1986) Elements in the Terrestrial Environment; 40-100, New York: Springer Verlag.

14. Bassuk, N.L. (1986) Reducing lead uptake in lettuce. Horticultural Science, 21 (4): 993-995.

15. Brown, S.L., Chaney, R., and Berti, B. (1999) Field test of amendments to reduce the in situ availability of soil lead. In Proceeding of 5th International Conference on the Biogeochemistry of Trace Elements; Wenzel, W.W., Adriano, D.C., Alloway, B., Doner, H.E., Keller, C., Lepp, N.W., Mench, M., Naidu, R. and Pierzynski, G.M., (eds)., Vol. 1, 506-507, Vienna, Austria.

16. Fischer, W.R. (1986) Properties of and heavy metal complexation by aqueous humic extracts. Z. Pflanzenernaehr. Bodenk, 149: 399-410.

17. Ullah, S.M. and Gerzabek, M.H. (1991) Influence of fulvic and humic acids on $\mathrm{Cu}$ - and V-toxicity to Zea mays (L). Bodenk, 42: 123-134.

18. Gerth, J. and Brümmer, G. (1983) Adsorption und Festlegung von Ni, Zn und Cd durch Goethit (alpha-FeOOH). Fresenius Z. Anal. Chem., 316: 616-620.

19. Nuruzzaman, M., Gerzabek, M.H., and Ullah, S.M. (1995) Studies on Heavy Metal and Microbiological Pollution of Soils, Sediments and Water Systems in and Around Dhaka City; 5-25, Austria, Vienna: Bericht an die Österr, Akademie der Wissenschaften: Austrian Research Centers Seibersdorf (ÖFZS).

20. Setia, R.C., Kaila, J., and Malik, C.P. (1988) Effects of nickel chloride toxicity on stem growth and ear development in Triticale aestivum (L). Phytomorphology, 38: 21-27.

21. Rubio, M.I., Escrig, I., Martinez, C., Lopez, C.F., and Sanz, A. (1994) Cadmium and nickel accumulation in rice plants, effects on mineral nutrition and possible interaction of abscisic and gibberelic acid. Plant Growth Regulators, 14: 151-157.

22. Mondol, M.N. (1995) Effect of Heavy Metals from Applied and Industrial Sources on Nutrient and Metal Uptake, Growth and Yield of Crops, M.Sc.Thesis; Department of Soil Science, 4-10, Dhaka, Bangladesh: University of Dhaka.

23. Schnitzer, M. and Khan, S.U. (1978) Soil Organic Matter; 34, Amsterdam: Elsevier Scientific Publishing Company.

24. Vaughan, D. and Malcolm, R.E. (1985) Soil Organic Matter and Biological Activity; 23, Dordrecht, Netherlands: Martinus Nijhoff/Dr. W. Junk Publishers.

25. Juste, C. (1980) Advantages et inconvenients de l'utulisation des composts d'ordures menageres comme amendent organique des sols on support, International Meeting on Composts, Madrid, Spain, 15.

26. Devleeschauwer, A., Verdonck, O., and Van Assche, P. (1981) Phytotoxicity of refuse compost. Biocycle, 22: 44-46.

27. Dyer, Y.M. and Razvi, A.S. (1987) Assessing risk of solid waste compost. Biocycle, 27: 31-36.

28. Petruzzelli, G., Guidi, G., and Lubrano, L. (1981) Influence of organic matter on lead adsorption by soil. Z. Pflanzenernaehr. Bodenkultur, 144: 74-76.

29. Gonzalez Sergio, P. (1994) Copper upper critical levels for plants on copperpolluted soils and the effect of organic additions. In Biogeochemistry of Trace 
Elements; Domy, C.A., Chen, Z.-S. and Yang, S.-S., eds.; Environmental Geochemistry and Health, 16, Boca Raton, FL: CRC Press.

30. Teasdale, R.D. (1987) Copper-induced indefinite aggregation of humic substances: Theoritical consequences for copper-binding behaviour. Journal of Soil Science, 38: $433-442$.

31. Hung, T.-C., Tsay, S.-C., and Meng, P.-J. (1994) Copper organically bound to humic substances and organic residues in Taiwan sediments. In Biogeochemistry of Trace Elements; Domy, C.A., Chen, Z.-S. and Yang, S.-S., eds.; Environmental Geochemistry and Health, 16, Boca Raton, FL: CRC Press.

32. Ram, N. and Verloo, M. (1985) Effect of various organic matter on the mobility of heavy metals in soil. Environmental Pollution (series B), 10: 241-248.

33. Petruzzelli, G., Guidi, G., and Lubrano, L. (1980) Chromatographic fractionation of heavy metals bound to organic matter of two Italian composts. Environmental Technology Letters, 1: 201.

34. Petruzzelli, G., Canarutto, S., and Lubrano, L. (1989) Effect of compost on distribution coefficients for $\mathrm{Zn}$ and $\mathrm{Cd}$ in soil. Agrochimica, $33(\mathrm{~N}): 45$.

35. Pierzynski, G.M. (1997) Strategies for remediating trace element contaminated sites. In Advances in Environmental Science: Remediation of Soils Contaminated with Metals; Iskandar, I.K. and Adriano, D.C., eds.; 67-84, Chelsea, MI: Lewis Publishers.

36. Miller, J.E., Hassett, J.J., and Koeppe, D.E. (1976) Uptake of Cd by soyabeans as influenced by soil cation exchange capacity, $\mathrm{pH}$ and available phosphorus. Journal Environmental Quality, 5: 157-160.

37. Zimdhal, R.L. and Foster, J.M. (1976) The influence of applied phosphorus manure or lime on uptake of lead from soil. Journal of Environmental Quality, 5 (1): $31-34$

38. Berti, W.R. and Cunningham, S.D. (1994) Remediating soil lead with green plants. In Trace Substances, Environment and Health: A Successor to the Series Trace Substances in Environmental Health; Cothern, C.R., ed.; 43-51, Northwood, ND: Science Reviews.

39. Brallier, S., Harrison, R.B., Henry, C.L., Xue, D., and Xue, D.S. (1996) Liming effects on availability of $\mathrm{Cd}, \mathrm{Cu}, \mathrm{Ni}$ and $\mathrm{Zn}$ in a soil amended with sewage sludge 16 years previously. Water, Air Soil Pollution, 86 (1-4): 195-206.

40. Andersson, A. and Siman, G. (1991) Levels of Cd and some other trace elements in soils and crops as influenced by lime and fertilizer level. Acta Agriculture Scandinavica, 41: 3-11.

41. Sauerbeck, D. (1982) Welche Schwermetallgehalte in Pflanzen dürfen nicht überschritten werden, um Wachstumsbeeinträchtigungen $\mathrm{zu}$ vermeiden? Landwintschaftlicke Forschung Sonderheft, Kongressband, 39: 108-129.

42. Bergmann, W. (1993) Ernährungsstörungen bei Kulturpflanzen, 3rd ed.; 1-3, Jena, Stuttgart: Gustav Fischer Verlag.

43. Sillanpää, M. (1984) Micronutrient availability as affected by some soil factors. In Reprint of 9th CIEC World Fertilizer Congress: Fight Against Hunger Through Improved Plant Nutrition, June 11-16; , White, E. and Szabolcs, J., eds.; 253-258, Budapest, Hungary: CTEC.

44. Brown, K.W. (1997) Decontamination of polluted soils. In Advances in Environmental Science: Remediation of Soils Contaminated with Metals; Iskander, I.K. and Adriano, D.C., eds.; 47-65, Chelsea, MI: Lewis Publishers.

45. Grove, J.H. and Ellis, B.G. (1980) Extractable $\mathrm{Cr}$ as related to soil $\mathrm{pH}$ and applied Cr. Soil Science Society of America Journal, 44: 238-242. 


\section{A. S. Chamon et al.}

46. Tokyo Metropolitan Government. (1980) Measures for Treating Soil Contamination Caused by Hexavalent Chromium in Tokyo; 1-15, Tokyo, Japan: Bureau of Environmental Protection, 1980.

47. Fu, G., Allen, H.E., and Cowan, C.E. (1991) Adsorption of cadmium and copper by manganese oxide. Soil Science, 152: 72-81.

48. Mench, M., Vangronsveld, J., Didier, V., and Clijsters, H. (1994) A mimicked in situ remediation study of metal contaminated soils with emphasis on cadmium and lead. Environmental Pollution, 86: 279-286.

49. Sappin-Didier, V.L., Mench, M.J., Gomez, A.N., and Lambrot, C. (1997) Use of inorganic amendments for reducing metal bioavailability to ryegrass and tobacco in contaminated soils. In Advances in Environmental Science: Remediation of Soils Contaminated with Metals; Iskander, I.K. and Adriano, D.C., eds.; 85-97, Chelsea, MI: Lewis Publishers.

50. Gerzabek, M.H. and Ullah, S.M. (1990) Influence of fulvic and humic acids on Cd- and Ni- toxicity to Zea mays (L.). Bodenkultur, 41: 115-124. 